\title{
Pengaruh Kondisi Keuangan Perusahaan, Sosialisasi Perpajakan, dan Sanksi Perpajakan pada Kepatuhan Wajib Pajak Hotel
}

\author{
Nyoman Nadia Naissa Deinara ${ }^{1}$ \\ I Ketut Jati ${ }^{2}$ \\ ${ }^{1,2}$ Fakultas Ekonomi dan Bisnis Universitas Udayana (Unud), Bali, Indonesia \\ e-mail: deinaranaissa@gmail.com
}

\begin{abstract}
ABSTRAK
Kepatuhan wajib pajak merupakan aspek terpenting dalam sistem perpajakan di Indonesia yang menganut self assesement system yang memberikan kepecayaan dalam menghitung, membayar, dan melaporkan sendiri besarnya pajak yang terutang. Penelitian ini bertujuan untuk menguji secara empiris pengaruh kondisi keuangan perusahaan, sosialisasi perpajakan, dan sanksi perpajakan pada kepatuhan wajib pajak hotel. Penelitian ini menggunakan data primer dengan cara penyebaran kuesioner. Populasi adalah seluruh wajib pajak hotel aktif yang terdaftar pada Badan Pendapatan Daerah Kabupaten Badung yaitu sejumlah 2.456 hotel. Metode penentuan sampel yang digunakan adalah metode accidental sampling dengan menggunakan rumus slovin, sehingga diperoleh sampel sebanyak 96 hotel dengan tahun pengamatan 3 tahun. Teknik analisis menggunakan analisis regresi linear berganda. Berdasarkan hasil analisis, ditemukan bahwa kondisi keuangan perusahaan, sosialisasi perpajakan, dan sanksi perpajakan berpengaruh positif terhadap kepatuhan wajib pajak hotel. Kata Kunci: Kondisi keuangan, sosialisasi pajak, sanksi pajak, kepatuhan pajak
\end{abstract}

\begin{abstract}
Compliance with taxpayers is the most important aspect in the taxation system in Indonesia which adheres to a self-assessment system that provides trust in calculating, paying, and reporting on the amount of tax payable. This study aims to empirically examine the effect of corporate financial conditions, tax socialization, and tax sanctions on hotel taxpayer compliance. This research uses primary data by distributing questionnaires. The population is all active hotel taxpayers registered with the Regional Revenue Agency of Badung Regency, which is 2,456 hotels. The method of determining the sample used is the accidental sampling method using the Slovin formula, so that a sample of 96 hotels was obtained with a 5 year observation year. The analysis technique uses multiple linear regression analysis. Based on the results of the analysis, it was found that the company's financial condition, tax socialization, and tax sanctions had a positive effect on hotel taxpayer compliance.
\end{abstract}

Keywords: Financial conditions, tax socialization, tax sanctions, tax compliance

\section{PENDAHULUAN}

Pembangunan nasional adalah kegiatan yang berlangsung secara terus-menerus dan berkesinambungan yang bertujuan untuk meningkatkan kesejahteraan rakyat. Tujuan tersebut dapat direalisasikan dengan memperhatikan masalah pembiayaan pembangunan, salah satunya dengan menggali dana yang berasal dari dalam 
negeri berupa pajak (kristina \& hariyani, n.d.). Indonesia merupakan negara yang menjadikan pajak sebagai sumber penerimaan utama negara dalam melaksanakan tugas pemerintahan dan pembangunan. Ini dikarenakan pajak tidak hanya menjadi salah satu anggaran pendapatan pokok negara, tetapi juga menjadi pendapatan terbesar yang dapat melangsungkan pembangunan negara. Berdasarkan Anggaran Pendapatan dan Belanja Negara (APBN) tahun 2017 memperlihatkan bahwa pendapatan negara ditetapkan sebesar Rp1.750,3 triliun, dimana 85,6 persen dari total pendapatan tersebut sebesar Rp1.498,9 triliun bersumber dari sektor perpajakan (http://www.fiskal.kemenkeu.go.id, 2018).

Pariwisata telah menjadi salah satu sektor yang paling diandalkan dalam pembangunan Bali, salah satu kabupaten yang memiliki potensi cukup besar adalah Kabupaten Badung. Beberapa tahun belakangan, kontribusi sektor lapangan usaha pariwisata khususnya perhotelan di Kabupaten Badung mengalami peningkatan yang sangat signifikan, maka dari itu dibutuhkan dana yang lebih memadai terutama untuk pembangunan infrastruktur. Pembiayaan dana tersebut dapat digali dari PAD salah satunya dari pajak hotel. Pajak hotel merupakan sumber pendapatan pajak daerah terbesar di Kabupaten Badung, tidak lain karena semakin banyaknya pengusaha dan investor yang tertarik membangun hotel maupun penginapan lainnya dengan berbagai kelas dan fasilitas untuk menunjang para wisatawan domestik maupun mancanegara. Bila dilihat perkembangan selama tiga tahun terakhir, jumlah wajib pajak hotel yang terdaftar pada Badan Pendapatan Daerah Kabupaten Badung disajikan pada Tabel 1. 


\section{Tabel 1.}

Perkembangan Wajib Pajak Hotel pada Badan Pendapatan Daerah Kabupaten Badung Tahun 2016-2018 (Dalam Unit)

\begin{tabular}{llcccc}
\hline \multirow{2}{*}{ Tahun } & $\begin{array}{c}\text { Hotel } \\
\text { Berbintang }\end{array}$ & $\begin{array}{c}\text { Hotel Non } \\
\text { Bintang }\end{array}$ & Villa & Rumah Kost & Jumlah \\
\hline 2016 & 208 & 643 & 1259 & 56 & 2.166 \\
2017 & 214 & 671 & 1479 & 92 & 2.456 \\
2018 & 226 & 693 & 1755 & 115 & 2.789 \\
\hline
\end{tabular}

Data dari Tabel 1 menunjukan bahwa jumlah wajib pajak hotel mengalami kenaikan setiap tahunnya, hal ini disebabkan karena Kabupaten Badung merupakan kawasan pariwisata yang paling luas di Bali dan sasaran utama para wisatawan khususnya mancanegara, sehingga jumlah hotel dan jenis penginapan lainnya juga akan bertambah seiring bertambahnya kunjungan wisatawan untuk memenuhi kebutuhannya. Peningkatan pada jumlah wajib pajak hotel setiap tahunnya tidak diimbangi dengan pembayaran pajak hotel tersebut. Salah satu penyebabnya adalah diduga banyak hotel yang belum terdaftar menjadi wajib pajak hotel serta adanya peralihan kepemilikan hotel dan kewajiban yang belum dilunasi oleh pihak (Sentanu \& Setiawan, 2016)

(Torgler, 2005) mengatakan bahwa permasalahan serius yang harus dihadapi oleh setiap pembuat kebijakan ekonomi adalah melakukan peningkatan kepatuhan wajib pajak. Kepatuhan wajib pajak merupakan pemenuhan kewajiban perpajakan yang dilakukan oleh wajib pajak dalam rangka memberikan kontribusi bagi pembangunan dewasa ini yang diharapkan didalam pemenuhannya diberikan secara sukerela dan tanpa paksaan. Menurut (Martin, 2010), kepatuhan perpajakan adalah ukuran secara teoritis dengan memperhatikan tiga jenis kepatuhan yakni kepatuhan pembayaran, penyimpanan, dan pelaporan. Kepatuhan wajib pajak 
menjadi aspek penting mengingat sistem perpajakan Indonesia menganut self assesment system dimana dalam prosesnya secara mutlak memberikan kepercayaan kepada wajib pajak untuk melakukan tiga jenis kepatuhan tersebut.

Ketidakpatuhan pajak menyebabkan berkurangnya penyetoran pajak ke kas negara secara bersamaan (Clotfetler, 1983) (Doran, 2009) berpendapat bahwa kepatuhan wajib pajak perlu ditumbuhkan secara terus menerus demi tercapainya target pajak. Kepatuhan pajak yang tidak meningkat otomatis akan menghambat kesejahteraan masyarakat (Chau, 2009). Kesadaran wajib pajak hotel di Kabupaten Badung dalam melakukan kewajibannya terbilang masih sangat rendah, ini dapat dilihat dari adanya tunggakan yang cukup besar di Badan Pendapatan Kabupaten Badung. Tabel 2. menyajikan jumlah tunggakan pajak hotel di Badan Pendapatan Kabupaten Badung.

Tabel 2.

Tunggakan Pajak Hotel Pada Badan Pendapatan Kabupaten Badung Tahun 2016-2018 (Dalam Rupiah)

\begin{tabular}{cc}
\hline Tahun & Jumlah $(\mathrm{Rp})$ \\
\hline 2016 & $82.528 .639 .203,33$ \\
2017 & $86.348 .139 .473,95$ \\
2018 & $89.529 .053 .823,81$ \\
\hline
\end{tabular}

Sumber: Badan Pendapatan Daerah Kabupaten Badung, 2018

Tabel 2. menyatakan tunggakan Pajak Hotel di Kabupaten Badung dari tahun 2016-2018. Hal ini mengindikasikan kesadaran wajib pajak untuk memenuhi kewajibannya semakin menurun. Menurut (Sentanu \& Setiawan, 2016), besarnya tunggakan ini terjadi disebabkan karena jumlah pajak yang terhutang digunakan untuk membiayai operasional hotel. Melihat situasi seperti ini, jumlah tunggakan akan terus meningkat dan akan mempengaruhi PAD Kabupaten Badung. Selain tunggakan pajak, jumlah realisasi penerimaan pajak 
hotel juga menunjukkan bukti ketidakpatuhan wajib pajak. Tabel 3. menyajikan jumlah target dan realisasi penerimaan pajak hotel di Badan Pendapatan Kabupaten Badung.

Tabel 3.

Jumlah Target dan Realisasi Penerimaan Pajak Hotel di Kabupaten Badung Tahun 2016-2018 (Dalam Juta Rupiah)

\begin{tabular}{llll}
\hline Tahun & Target & Realisasi & Persentase \\
\hline 2016 & 1.644 .235 & 1.872 .337 & 107.87 \\
2017 & 2.013 .908 & 1.773 .684 & 92.98 \\
2018 & 3.514 .966 & 1.402 .841 & 45.60 \\
\hline
\end{tabular}

Sumber: Badan Pendapatan Daerah Kabupaten Badung, 2018

Berdasarkan Tabel 3 dapat dlihat bahwa persentase antara target dan realisasi penerimaan pajak hotel di kabupaten badung terus mengalami penurunan, dan yang signifikan terjadi pada tahun 2018. Hal ini dikarenakan pemerintah kabupaten badung menetapkan angka target yang cukup tinggi, sehingga persentase antara target dan realisasi menurun drastis dibandingkan tahun lalu. Namun, jika dilihat pada realisasi penerimaannya sendiri memang tidak mengalami peningkatan dari tahun 2016. Maka dari itu, perlu diteliti kembali faktor-faktor yang mempengaruhi kepatuhan wajib pajak hotel di kabupaten badung.

Tinggi rendahnya wajib pajak dalam mematuhi kewajiban perpajakannya dipengaruhi oleh beberapa faktor, salah satunya adalah keuangan perusahaan. Kondisi keuangan dapat didefinisikan dengan kemampuan keuangan perusahaan yang tercermin dari tingkat profitabilitas (profitability) dan arus kas (cash flow) (Laksono, 2012). Profitabilitas perusahaan merupakan faktor yang mempengaruhi perusahaan dalam mematuhi peraturan perpajakan. Perusahaan dengan 
profitabilitas rendah akan mengalami kesulitan keuangan dan tidak menaati peraturan perpajakan.

Untuk meningkatkan kepatuhan wajib pajak, salah satu upaya dari Direktorat Jenderal pajak adalah dengan mengadakan sosialisasi perpajakan. Menurut (Sulistyaningrum, 2009), sosialisasi perpajakan merupakan upaya dalam memberikan informasi kepada masyarakat tentang segala hal perpajakan. (Lidya, 2013) berpendapat bahwa sosialisasi akan berdampak pada pengetahuan masyarakat yang akhirnya menyebabkan tingkat kesadaran masyarakat menjadi rendah. Faktor lain yang mempengaruhi kepatuhan wajib pajak adalah sanksi. Pengenaan sanksi perpajakan dilakukan dengan tujuan untuk meningkatkan kesadaran masyarakat sendiri, dengan kata lain ketegasan sanksi merupakan alat mencegah (preventif) agar wajib pajak tidak melanggar norma perpajakan, karena wajib pajak akan memenuhi kewajiban perpajakannya bila memandang bahwa sanksi perpajakan akan lebih banyak merugikannya (Sapriadi, 2013).

Teori atribusi menjelaskan tentang pemahaman akan reaksi seseorang terhadap peristiwa di sekitar mereka, dengan mengetahui alasan-alasan mereka atas kejadian yang dialami. Teori atribusi menjelaskan penyebab internal yang mengacu pada aspek perilaku individual yang ada dalam diri seseorang. Hubungannya dengan kondisi keuangan adalah dalam menentukan perilaku wajib pajak terhadap pemenuhan kewajiban pajaknya. Kondisi keuangan yang baik merupakan faktor internal yang akan membentuk aspek perilaku individu yaitu kepatuhan wajib pajak. Salah satu faktor internal yaitu kondisi keuangan akan 
berakibat kepada perilaku yang timbul dari wajib pajak yaitu kepatuhan membayar pajak.

Perusahaan yang mempunyai profitabilitas tinggi cenderung lebih jujur dalam melaporkan pajaknya dari pada perusahaan yang mempunyai profitabilitas rendah. Perusahaan dengan profitabilitas rendah pada umumnya mengalami kesulitan keuangan (financial difficulty) dan cenderung melakukan ketidakpatuhan pajak. Tingkat beban hutang yang tinggi memungkinkan perusahaan dalam mematuhi peraturan perpajakan. Saat wajib pajak memiliki kondisi keuangan yang cukup baik dan cenderung stabil, untuk selanjutnya kondisi keuangan dapat meningkatkan kepatuhan wajib pajak. Pernyataan ini didukung dengan hasil penelitian yang dilakukan oleh (Laksono, 2012), (Aryobimo, 2012), (Prayatni \& Jati, 2016). yang memperoleh hasil penelitian bahwa kondisi keuangan perusahaan berpengaruh pada kepatuhan wajib pajak hotel. Berdasarkan uraian diatas maka hipotesis pertama yang diajukan dalam penelitian ini adalah:

$\mathrm{H}_{1}$ : Kondisi keuangan perusahaan berpengaruh positif pada kepatuhan wajib pajak hotel di Kabupaten Badung.

Teori legitimasi sangat berpengaruh terhadap sosialisasi perpajakan, jika tidak ada keselarasan sistem nilai antara perusahaan dengan masyarakat, maka perusahaan tersebut akan kehilangan legitimasinya yang dapat mengancam kelangsungan hidup perusahaan. Sosialisasi yang diberikan untuk memberikan pengertian akan pentingnya membayar pajak, sehingga dengan adanya sosialisasi ini masyarakat mengetahui manfaat membayar pajak . 
Nyoman Nadia Naissa Deinara dan I Ketut Jati. Pengaruh ...

Sosialisasi perpajakan memiliki peran yang sangat penting dalam memenuhi peraturan perpajakan. Kesadaran wajib pajak akan meningkat jika sosialisasi diadakan secara rutin. Penelitian yang dilakukan. menunjukan bahwa sosialisasi memiliki pengaruh yang positif dalam meningkatkan kepatuhan wajib pajak. Selain itu, penelitian yang dilakukan oleh (Hartana \& Merkusiwati, 2018) menunjukkan bahwa variabel sosialisasi perpajakan berpengaruh positif pada kepatuhan wajib pajak. Berdasarkan hal tersebut, maka hipotesis kedua yang diajukan pada penelitian ini adalah:

$\mathrm{H}_{2}$ : Sosialisasi perpajakan berpengaruh positif pada kepatuhan wajib pajak hotel di Kabupaten Badung.

Berdasarkan teori atribusi, sanksi pajak termasuk dalam penyebab eksternal karena adanya pengaruh persepsi wajib pajak dalam membuat penilaian mengenai perilaku kepatuhan wajib pajak dalam melaksanakan kewajiban perpajakan. Berdasarkan teori pembelajaran sosial, wajib pajak dapat belajar melalui proses pengalaman dan pengamatan dalam pemberian sanksi pajak oleh aparat pajak kepada wajib pajak yang melanggar norma perpajakan.

Menurut (Lederman, 2003) berpendapat bahwa wajib pajak memenuhi kewajibannya dikarenakan kepatuhan terhadap pajak dianggap sebagai sebuah norma. Sanksi perpajakan merupakan alat pencegah (preventif) agar wajib pajak tidak melanggar norma (Mardiasmo, 2011). Jika wajib pajak memandang bahwa sanksi perpajakan akan memberikan banyak kerugian, untuk selanjutnya sanksi perpajakan dapat memberikan pelajaran bagi pelanggar pajak dan meningkatkan kepatuhan wajib pajak. Berdasarkan penelitian yang dilakukan oleh (Rahayu, 2010) manunjukkan bahwa sanksi perpajakan berpengaruh terhadap 
kepatuhan wajib pajak hotel. Pernyataan ini juga didukung oleh hasil penelitian yang dilakukan oleh (Pratiwi \& Setiawan, 2013). Berdasarkan uraian tersebut, hipotesis ketiga pada penelitian ini adalah:

$\mathrm{H}_{3}$ : $\quad$ Sanksi perpajakan berpengaruh positif pada kepatuhan wajib pajak hotel di Kabupaten Badung.

\section{METODE PENELITIAN}

Penelitian yang digunakan dalam penelitian ini adalah penelitian kuantitatif yang bersifat asiosiatif. Penelitian asiosiatif adalah penelitian yang bertujuan untuk mengetahui hubungan antara dua variabel atau lebih (Sugiyono, 2016). Kerangka konseptual penelitian dapat ditunjukkan oleh Gambar 1. Berikut

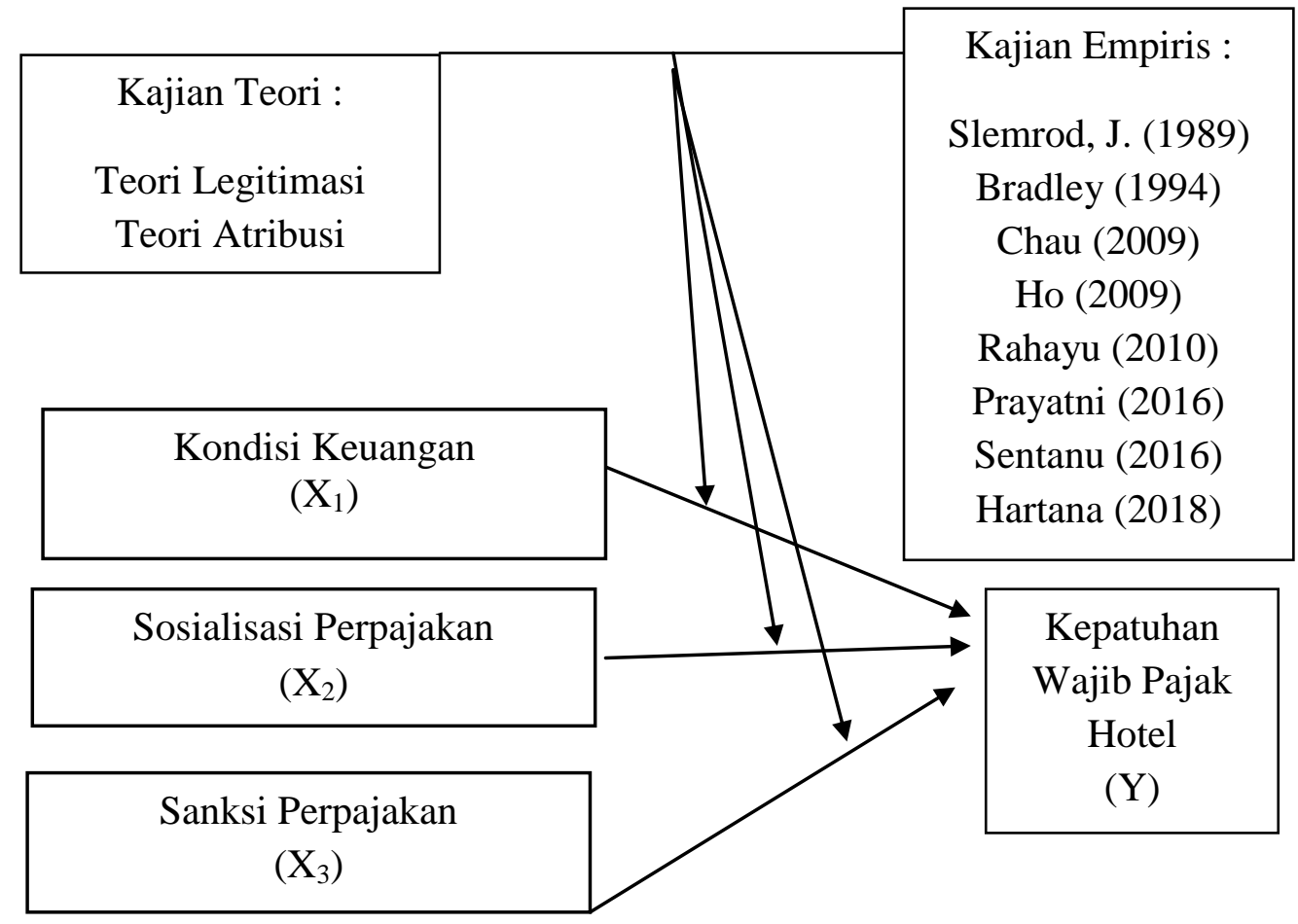

Sumber : Data diolah, 2018

\section{Gambar 1. Kerangka Konseptual Penelitian}

Lokasi penelitian dilakukan di Badan Pendapatan Daerah Kabupaten

Badung yang beralamat di Jl. Raya Sempidi, Badung. Pemilihan pada Badan 
Pendapatan Daerah Kabupaten Badung didasarkan pada jumlah piutang pajak hotel dari tahun 2016-2018 yang mengalami penurunan jumlah tunggakan pajak, serta target penerimaan dan jumlah realisasi penerimaan pajak yang tidak sebanding. Fenomena ini terjadi karena kurangnya kesadaran dari kepatuhan wajib pajak hotel sehingga peneliti tertarik untuk meneliti faktor-faktor yang mempengaruhi kepatuhan wajib pajak hotel.

Obyek dalam penelitian ini adalah kepatuhan wajib pajak hotel yang terdaftar di Badan Pendapatan Daerah Kabupaten Badung, khususnya mengenai kondisi keuangan perusahaan, sosialisasi perpajakan, dan sanksi perpajakan. Variabel terikat dalam penelitian ini adalah kepatuhan wajib pajak hotel. Sedangkan variabel bebas dalam penelitian ini adalah kondisi keuangan perusahaan (X1), sosialisasi perpajakan (X2), sanksi perpajakan (X3).

Populasi dalam penelitian ini adalah seluruh wajib pajak hotel aktif yang terdaftar pada Badan Pendapatan Daerah Kabupaten Badung tahun 2017 yaitu sejumlah 2.456 Wajib Pajak Hotel. Metode penentuan sampel menggunakan metode accidental sampling yaitu teknik penentuan sampel berdasarkan kebetulan, yaitu siapa saja yang secara kebetulan bertemu dengan peneliti dapat digunakan sebagai sampel, bila orang yang kebetulan ditemui dipandang cocok sebagai sumber data (Sugiyono, 2016). Adapun yang menjadi kriteria responden dalam penelitian ini adalah seluruh wajib pajak hotel yang terdaftar di Badan Pendapatan Daerah Kabupaten Badung. Berdasarkan kriteria tersebut, jumlah sampel yang digunakan dalam penelitian ini adalah sejumlah 96 wajib pajak hotel. Sembilan puluh enam wajib pajak hotel yang digunakan sebagai sampel diperoleh 
berdasarkan perhitungan penentuan sampel dengan menggunakan rumus Slovin (Husein, 2008:78), yaitu :

$$
\mathrm{n}=\quad \frac{\mathrm{N}}{\left(1+\mathrm{Ne}^{2}\right)}
$$

Keteranggan:

$\mathrm{n}=$ Jumlah anggota sampel

$\mathrm{N}=$ Jumlah anggota populasi

$\mathrm{E}=$ Nilai kritis (batas kesalahan 0,1)

$$
\begin{aligned}
\mathrm{n} & =\frac{2.456}{\left(1+2.456(0,1)^{2}\right)} \\
& =96,087 \\
& =96 \text { (dibulatkan) }
\end{aligned}
$$

Pengumpulan data dalam penelitian ini menggunakan teknik observasi non partisipan berupa perkembangan jumlah wajib pajak hotel, jumlah tunggakan pajak hotel yang terdaftar pada Badan Pendapatan Daerah Kabupaten Badung, sejarah berdirinya Badan Pendapatan Daerah Kabupaten Badung, struktur organisasi Badan Pendapatan Daerah Kabupaten Badung, uraian bidang tugas dan kegiatan Badan Pendapatan Daerah Kabupaten Badung. Selain itu juga menggunakan kuesioner. Pemberian kuesioner dapat dilakukan dengan mendatangi dan memberikan secara langsung kepada responden, dan kuesioner yang telah diisi dikembalikan secara langsung kepada peneliti. Hasil jawaban kemudian diukur dengan menggunakan skala likert, yaitu pilihan responden diberi nilai dengan skala 4 poin, skor tertinggi adalah 4 dan skor terendah yaitu 1 .

Jenis data yang digunakan dalam penelitian ini adalah data kuantitatif berupa data perkembangan jumlah wajib pajak hotel dan jumlah piutang pajak 
hotel di Badan Pendapatan Daerah Kabupaten Badung. Data kualitatif dalam penelitian ini berupa seluruh bentuk informasi yang berkaitan dengan organisasi Badan Pendapatan Daerah Kabupaten Badung yang berupa sejarah, gambaran umum, dan struktur organisasi. Sedangkan sumber data yang digunakan dalam penelitian ini adalah data primer berupa jawaban kuesioner dari responden. Data sekunder dalam penelitian ini berupa data jumlah wajib pajak hotel, tunggakan pajak, gambaran umum, sejarah, serta struktur organisasi Badan Pendapatan Daerah Kabupaten Badung.

Teknik analisis data yang digunakan dalam penelitian ini adalah teknik analisis regresi linier berganda. Uji asumsi klasik dalam penelitian ini mencakup uji normalitas, multikolinearitas, dan heteroskedastisitas. Model regresi linier berganda dirumuskan sebagai berikut.

$$
\mathrm{Y}=\alpha+\beta_{1} \mathrm{X}_{1}+\beta_{2} \mathrm{X}_{2}+\beta_{3} \mathrm{X}_{3}+\mathrm{e}
$$

\section{Keterangan}

$\mathrm{Y} \quad=$ Kepatuhan Wajib Pajak

$\alpha \quad=$ Nilai konstanta

$\mathrm{X}_{1} \quad=$ Kondisi Keuangan Perusahaan

$\mathrm{X}_{2} \quad=$ Sosialisasi Perpajakan

$\mathrm{X}_{3} \quad=$ Sanksi Perpajakan

$\beta_{1} \quad=$ Koefisien regresi dari Kondisi Keuangan Perusahaan (X1)

$\beta_{2} \quad=$ Koefisien regresi dari Sosialisasi Perpajakan (X2)

$\beta_{3} \quad=$ Koefisien regresi dari Sanksi Perpajakan (X3)

e $\quad=$ Standar error

\section{HASIL DAN PEMBAHASAN}

Responden penelitian ini adalah seluruh wajib pajak hotel yang terdaftar di Badan Pendapatan Daerah Kabupaten Badung yaitu sejumlah 96 wajib pajak hotel. 
Karakteristik responden meliputi jenis kelamin, tingkat pendidikan terakhir, jabatan dan lama kerja dapat dilihat pada Tabel 4.

Tabel 4.

Karakteristik Responden

\begin{tabular}{cccc}
\hline $\begin{array}{c}\text { Karakteristik } \\
\text { Responden }\end{array}$ & Keterangan & $\begin{array}{c}\text { Jumlah } \\
(\text { Orang })\end{array}$ & $\begin{array}{c}\text { Persentase } \\
(\%)\end{array}$ \\
\hline \multirow{3}{*}{ Jenis Kelamin } & Laki-laki & 54 & 56.25 \\
& Perempuan & 42 & 43.75 \\
& Total & 96 & 100.00 \\
SMA/Sederajat & 10 & 10.42 \\
Pendidikan & Diploma 3 (D3) & 26 & 27.08 \\
Terakhir & Strata 1 (S1) & 41 & 42.71 \\
& Strata 2 (S2) & 14 & 14.58 \\
& Strata 3 (S3) & 5 & 5.21 \\
& Total & 96 & 100.00 \\
Jabatan & Accounting Department & 44 & 45.83 \\
& Human Resources Department & 29 & 30.21 \\
& Supervisor & 17 & 17.71 \\
& General Manager & 6 & 6.25 \\
& Total & 96 & 100.00 \\
& 1-5 Tahun & 16 & 16.67 \\
Lama kerja & 5-10 Tahun & 31 & 32.29 \\
& $>10-15$ Tahun & 42 & 43.75 \\
& 15 Tahun & 7 & 7.29 \\
& Total & 96 & 100.00
\end{tabular}

Sumber: Data diolah, 2018

Karakteristik responden penelitian ini merupakan profil dari 96 responden yang berpartisipasi dalam pengisian kuesioner. Bedasarkan Tabel 4. di atas dapat dijelaskan bahwa wajib pajak yang berjenis kelamin laki-laki sebanyak 54 orang (56,25 persen) dan wajib pajak yang berjenis kelamin perempuan sebanyak 42 orang (43,75 persen). Hal ini menunjukkan bahwa dalam penelitian ini mayoritas yang bertugas untuk menangani wajib pajak hotel di Kabupaten Badung adalah responden laki-laki.

Pengelompokan responden berdasarkan tingkat pendidikan terakkhir menunjukkan tingkat pendidikan S1 mendominasi dengan jumlah sebanyak 41 orang wajib pajak (42,71 persen), sebanyak 26 orang wajib pajak (27,08 persen) 
Nyoman Nadia Naissa Deinara dan I Ketut Jati. Pengaruh ...

memiliki tingkat pendidikan diploma, sebanyak 14 orang wajib pajak $(14,58$ persen) memiliki tingkat pendidikan S2, sebanyak 10 orang wajib pajak $(10,42$ persen) memiliki tingkat pendidikan SMA dan sisanya 5 orang wajib pajak $(5,21$ persen) memiliki tingkat pendidikan S3.

Profil terkait jabatan menunjukkan kelompok jabatan responden yang bertanggung jawab dalam membayar pajak hotel di Kabupaten Badung. Responden dengan jabatan accounting department sebanyak 44 orang $(45,83$ persen), responden dengan jabatan human resources departement sebanyak 29 orang (30,21 persen), responden dengan jabatan supervisor sebanyak 17 orang (17,71 persen), dan sisanya sebanyak 6 orang adalah responden dengan jabatan sebagai general manager. Hal ini menunjukkan bahwa dalam penelitian ini responden yang bertanggungjawab dalam membayar pajak hotel di Kabupaten Badung mayoritas adalah responden dengan jabatan accounting department.

Kriteria responden berdasarkan profil lama kerja merupakan indikator untuk mengetahui lama responden bekerja pada salah satu hotel di Kabupaten Badung. Responden yang memiliki masa kerja antara 1 sampai 5 tahun sebanyak 16 orang (16,67 persen), selanjutnya responden yang bekerja selama lebih dari 5 sampai 10 tahun sebanyak 31 orang (32,29 persen), responden yang bekerja selama lebih dari 10 sampai 15 tahub sebanyak 42 orang (43,75 persen) dan sisanya yang bekerja lebih dari 15 tahun sebanyak 7 orang (7,29 persen). Hal ini mnunjukkan bahwa dalam penelitian ini responden yang bertanggungjawab dalam membayar pajak hotel di Kabupaten Badung mayoritas adalah responden dengan masa kerja lebih dari 10 sampai 15 tahun. 
Suatu instrumen dalam penelitian dikatakan valid apabila mampu mengukur apa yang ingin diukur. Tabel 5. berikut menyajikan hasil uji validitas instrumen penelitian.

Tabel 5.

Hasil Uji Validitas Instrumen Penelitian

\begin{tabular}{ccccc}
\hline Variabel & Indikator & Koefisien Korelasi & Sig. (2-tailed) & Keterangan \\
\hline \multirow{3}{*}{ Kondsi keuangan } & $\mathrm{X}_{1.1}$ & 0,680 & 0,000 & Valid \\
perusahaan $\left(\mathrm{X}_{1}\right)$ & $\mathrm{X}_{1.2}$ & 0,832 & 0,000 & Valid \\
& $\mathrm{X}_{1.3}$ & 0,741 & 0,000 & Valid \\
& $\mathrm{X}_{1.4}$ & 0,702 & 0,000 & Valid \\
& $\mathrm{X}_{2.1}$ & 0,694 & 0,000 & Valid \\
& $\mathrm{X}_{2.2}$ & 0,545 & 0,000 & Valid \\
Sosialisasi perpajakan & $\mathrm{X}_{2.3}$ & 0,594 & 0,000 & Valid \\
(X $)$ & $\mathrm{X}_{2.4}$ & 0,682 & 0,000 & Valid \\
& $\mathrm{X}_{2.5}$ & 0,661 & 0,000 & Valid \\
& $\mathrm{X}_{2.6}$ & 0,694 & 0,000 & Valid \\
& $\mathrm{X}_{2.7}$ & 0,673 & 0,000 & Valid \\
& $\mathrm{X}_{2.8}$ & 0,700 & 0,000 & Valid \\
& $\mathrm{X}_{3.1}$ & 0,719 & 0,000 & Valid \\
& $\mathrm{X}_{3.2}$ & 0,675 & 0,000 & Valid \\
& $\mathrm{X}_{3.3}$ & 0,699 & 0,000 & Valid \\
& $\mathrm{X}_{3.4}$ & 0,585 & 0,000 & Valid \\
& $\mathrm{X}_{3.5}$ & 0,726 & 0,000 & Valid \\
Kanksi Perpajakan $\left(\mathrm{X}_{3}\right)$ & $\mathrm{Y}_{1}$ & 0,561 & 0,000 & Valid \\
& $\mathrm{Y}_{2}$ & 0,652 & 0,000 & Valid \\
& $\mathrm{Y}_{3}$ & 0,721 & 0,000 & Valid \\
& $\mathrm{Y}_{4}$ & 0,741 & 0,000 & Valid \\
\hline
\end{tabular}

Sumber: Data diolah, 2018

Hasil uji validitas pada Tabel 5. menunjukkan bahwa seluruh instrumen penelitian yang digunakan untuk mengukur variabel kondisi keuangan perusahaan, sosialisasi perpajakan, sanksi perpajakan, dan kepatuhan wajib pajak memiliki nilai koefisien korelasi lebih besar dari 0,30 dan nilai signifikasi kurang dari 0,05 . Hal ini menunjukkan bahwa butir-butir pernyataan dalam instrument penelitian tersebut valid dan layak digunakan sebagai instrument penelitian. 
Nyoman Nadia Naissa Deinara dan I Ketut Jati. Pengaruh ...

Uji Reliabilitas terhadap instrumen penelitian ini menggunakan nilai Alpha Cronbach, yakni untuk mengetahui unidimensionalitas butir-butir pernyataan terhadap variabel laten yang diteliti (kondisi keuangan perusahaan, sosialisasi perpajakan, sanksi perpajakan dan kepatuhan wajib pajak). Nilai Alpha Cronbach dinyatakan reliabel jika nilainya lebih besar atau sama dengan 0,60. Rekapitulasi hasil uji reliabilitas instrumen penelitian dapat dilihat pada Tabel 6. berikut.

Tabel 6.

Hasil Uji Reliabilitas Instrumen Penelitian

\begin{tabular}{clcc}
\hline No. & \multicolumn{1}{c}{ Variabel } & Cronbach's Alpha & Keterangan \\
\hline 1 & Kondisi keuangan perusahaan $\left(\mathrm{X}_{1}\right)$ & 0,792 & Reliabel \\
2 & Sosialisasi perpajakan $\left(\mathrm{X}_{2}\right)$ & 0,762 & Reliabel \\
3 & Sanksi Perpajakan $\left(\mathrm{X}_{3}\right)$ & 0,771 & Reliabel \\
4 & Kepatuhan Wajib Pajak $(\mathrm{Y})$ & 0,763 & Reliabel \\
\hline \multicolumn{2}{l}{ Sumber: } & Data diolah, 2018
\end{tabular}

Hasil uji reliabilitas yang disajikan dalam Tabel 6. menunjukkan bahwa seluruh instrumen penelitian memiliki koefisien Cronbach's Alpha lebih dari 0,60. Jadi dapat dinyatakan bahwa seluruh variabel telah memenuhi syarat reliabilitas atau kehandalan sehingga dapat digunakan untuk melakukan penelitian.

Uji normalitas menggunakan uji Kolmogorov-Smirnov, dengan uji ini dapat diketahui data yang digunakan berdistribusi normal atau tidak. Apabila Sign t hitung $>0.05$, maka data tersebut berdistribusi normal dan begitu juga sebaliknya (Santoso, 2001). 
Tabel 7.

Hasil Uji Normalitas

\begin{tabular}{cc}
\hline & Unstandardized Residual \\
\hline $\mathrm{N}$ & 96 \\
Kolmogorov-Smirnov $Z$ & 0,519 \\
Asymp.Sig.(2-tailed) & 0,951 \\
\hline
\end{tabular}

Sumber: Data diolah, 2018

Berdasarkan hasil analisis didapat nilai signifikansi sebesar 0,951 seperti yang ditunjukkan oleh Tabel 7 Karena nilai signifikansi uji Kolmogorov-Smirnov lebih dari 0,05 maka dapat disimpulkan bahwa model persamaan regresi tersebut berdistribusi normal.

Uji multikolinieritas digunakan untuk mengetahui apakah antara variabel bebas terjadi multikolinieritas atau tidak. Uji yang digunakan yaitu dengan melihat nilai VIF (Varian Inflation Factor) dan Tolerance pada proses regresi biasa, jika keduanya mendekati 1 atau besaran VIF kurang dari 10 maka model tidak terkena multikolinieritas. Berdasasrkan hasil pengujian multikolinearitas dapat diperoleh hasil sebagai berikut.

Tabel 8.

Hasil Uji Multikoleniaritas

\begin{tabular}{lccc}
\hline \multicolumn{1}{c}{ Variabel } & Tolerance & VIF & Keterangan \\
\hline Kondisi keuangan perusahaan $\left(\mathrm{X}_{1}\right)$ & 0,636 & 1,571 & Bebas multikolinieritas \\
Sosialisasi perpajakan $\left(\mathrm{X}_{2}\right)$ & 0,454 & 2,202 & Bebas multikolinieritas \\
Sanksi Perpajakan $\left(\mathrm{X}_{3}\right)$ & 0,593 & 1,687 & Bebas multikolinieritas \\
\hline
\end{tabular}
Sumber: Data diolah, 2018

Berdasarkan Tabel 8 dapat dilihat bahwa nilai tolerance dan VIF dari seluruh variable tersebut menunjukkan bahwa nilai tolerance untuk setiap variabel lebih besar dari 10 persen dan nilai VIF lebih kecil dari 10 yang berarti model persamaan regresi bebas dari multikolinearitas. 
Uji Heterokedastisitas dilakukan untuk menguji apakah dalam model regresi terjadi ketidaksamaan varian dari residu satu pengamatan ke pengamatan lain. Model regresi yang baik adalah model homokedastisitas atau tidak terjadi heterokedastisitas. Apabila model suatu regresi mengandung gejala heterokedastisitas, maka hasil yang diberikan akan menyimpang. Untuk mengetahui apakah sebuah regresi memiliki indikasi heterokedastisitas, maka masalah tersebut bisa dideteksi dengan menggunakan uji Glejser Test. Jika probabilitas signifikansinya di atas 0,05 maka dapat dikatakan bahwa pada model regresi tidak mengandung masalah heterokedastisitas . Hasil uji heterokedastisitas dapat dilihat pada Tabel 9.

Tabel 9.

Hasil Uji Heteroskedastisitas

\begin{tabular}{lcc}
\hline \multicolumn{1}{c}{ Variabel } & Signifikansi & Keterangan \\
\hline Kondisi keuangan perusahaan $\left(\mathrm{X}_{1}\right)$ & 0,297 & Bebas Heteroskedastisitas \\
Sosialisasi perpajakan $\left(\mathrm{X}_{2}\right)$ & 0,266 & Bebas Heteroskedastisitas \\
Sanksi Perpajakan $\left(\mathrm{X}_{3}\right)$ & 0,417 & Bebas Heteroskedastisitas \\
\hline Sumber: Data diolah, 2018 & &
\end{tabular}

Pada Tabel 9 dapat dilihat bahwa nilai signifikansi dari variabel kondisi keuangan perusahaan sebesar 0,297, sosialisasi perpajakan sebesar 0,266 dan sanksi perpajakan sebesar 0,417 . Nilai tersebut lebih besar dari 0,05 yang berarti tidak terdapat pengaruh antara variabel bebas terhadap absolute residual. Dengan demikian, model yang dibuat tidak mengandung gejala heteroskedastisitas.

Perhitungan koefisien regresi linier berganda dilakukan dengan analisis regresi melalui software SPSS 18.0 for Windows, diperoleh hasil yang ditunjukan pada Tabel 10. 
Tabel 10.

Hasil Analisis Regresi Linier Berganda

\begin{tabular}{|c|c|c|c|c|c|c|}
\hline \multirow[t]{2}{*}{ Model } & \multicolumn{2}{|c|}{$\begin{array}{c}\text { Unstandardized } \\
\text { Coefficients }\end{array}$} & \multicolumn{2}{|c|}{$\begin{array}{l}\text { Standardized } \\
\text { Coefficients }\end{array}$} & \multirow[b]{2}{*}{$\mathrm{t}$} & \multirow[b]{2}{*}{ Sig. } \\
\hline & $\mathrm{B}$ & Std. Error & Beta & & & \\
\hline (Constant) & 2.264 & .941 & & & 2.405 & .018 \\
\hline Kondisi keuangan perusahaan & .154 & .065 & & .197 & 2.351 & .021 \\
\hline Sosialisasi perpajakan & .096 & .044 & & .216 & 2.181 & .032 \\
\hline Sanksi Perpajakan & .391 & .070 & & .488 & 5.618 & .000 \\
\hline$R$ Square & & & 0,589 & & & \\
\hline F hitung & & & 43,870 & & & \\
\hline Signifikansi F & & & 0,000 & & & \\
\hline
\end{tabular}

Sumber: Data diolah, 2018

Berdasarkan hasil analisis regresi linier berganda seperti yang disajikan pada Tabel 10., maka dapat dibuat persamaan regresi sebagai berikut:

$$
Y=2,264+0,154 X_{1}+0,096 X_{2}+0,391 X_{3}
$$

Nilai koefisien regresi masing-masing variabel bebas bernilai positif dengan nilai signifikansi uji t kurang dari 0,05 . Hal ini menunjukkan bahwa semua variabel bebas memiliki pengaruh positif yang signifikan terhadap variabel terikat.

Besarnya pengaruh variabel bebas terhadap variabel terikat yang ditunjukkan oleh nilai determinasi total (R Square) sebesar 0,589 mempunyai arti bahwa sebesar 58,9 persen variasi kepatuhan wajib pajak hotel dipengaruhi oleh variasi kondisi keuangan perusahaan, sosialisasi perpajakan, dan sanksi perpajakan, sedangkan sisanya sebesar 41,1 persen djelaskan oleh faktor lain yang tidak dimasukkan ke dalam model.

Uji kelayakan model regresi bertujuan untuk mengetahui apakah semua variabel bebas yang diidentifikasi (kondisi keuangan perusahaan, sosialisasi perpajakan, dan sanksi perpajakan) tepat digunakan memprediksi kepatuhan wajib pajak. Hasil pengolahan data pada tabel 10 diperoleh nilai $\mathrm{F}_{\text {hitung }}$ sebesar 43,870 dengan signifkansi sebesar $0,000<0,05$, maka dapat disimpulkan bahawa pada 
kelompok yang diuji memiliki perbedaan yang nyata (signifikan). Hasil ini mempunyai arti bahwa ada pengaruh signifikan antara faktor kondisi keuangan perusahaan, sosialisasi perpajakan, dan sanksi perpajakan secara simultan terhadap kepatuhan wajib pajak hotel yang terdaftar di Badan Pendapatan Daerah Kabupaten Badung.

Pengaruh variabel kondisi keuangan perusahaan, sosialisasi perpajakan dan sanksi perpajakan terhadap kepatuhan wajib pajak hotel diuji dengan menggunakan Uji t. Kriteria pengujian untuk menjelaskan interpretasi pengaruh antar masing-masing variabel yakni apabila nilai signifikansi $<0,05$ maka $\mathrm{H}_{0}$ ditolak dan $\mathrm{H}_{1}$ diterima. Sebaliknya, jika nilai signifikansi > 0,05 maka $\mathrm{H}_{0}$ diterima dan $\mathrm{H}_{1}$ ditolak.

Berdasarkan Tabel 10. diperoleh nilai t hitung sebesar 2.351 sedangkan nilai t tabel sebesar 2.366, dan nilai signifikansi uji t yakni nilai $p$-value sebesar 0,021 $<0,05$ dengan nilai koefisien regresi sebesar 0,154. Ini berarti bahwa kondisi keuangan perusahaan berpengaruh positif, sehingga hipotesis pertama penelitian ini diterima.

Pengaruh kondisi keuangan perusahaan terhadap kepatuhan wajib pajak hotel ini sesuai dengan teori atribusi. Hubungannya dengan kondisi keuangan adalah dalam menentukan perilaku wajib pajak terhadap pemenuhan kewajiban pajaknya. Kondisi keuangan yang baik merupakan faktor internal yang akan membentuk aspek perilaku individu yaitu kepatuhan wajib pajak. Salah satu faktor internal yaitu kondisi keuangan akan berakibat kepada perilaku yang timbul dari wajib pajak yaitu kepatuhan membayar pajak. 
Pernyataan ini didukung dengan hasil penelitian yang dilakukan oleh (Laksono, 2012), (Aryobimo, 2012), (Prayatni \& Jati, 2016) yang memperoleh hasil penelitian bahwa kondisi keuangan perusahaan berpengaruh terhadap kepatuhan wajib pajak hotel.

Berdasarkan Tabel 10. diperoleh nilai t hitung sebesar 2.181 sedangkan nilai t tabel sebesar 2.366, dan nilai signifikansi uji t yakni nilai $p$-value sebesar 0,032 $<0,05$ dengan nilai koefisien regresi sebesar 0,096. Ini berarti bahwa sosialisasi perpajakan berpengaruh positif pada kepatuhan wajib pajak hotel, sehingga hipotesis kedua penelitian ini diterima.

Hasil analisis menunjukkan bahwa sosialisasi perpajakan berpengaruh positif dan signifikan terhadap kepatuhan wajib pajak hotel. Hal ini berarti bahwa apabila sosialisasi perpajakan yang diberikan semakin efektif maka kepatuhan wajib pajak dalam membayar pajak akan semakin meningkat. Begitu pula sebaliknya, semakin tidak efektif sosialisasi perpajakan yang diberikan maka kepatuhan wajib pajak juga akan semakin menurun.

Sosialisasi perpajakan memiliki peran yang sangat strategis untuk mendorong dan meningkatkan kepatuhan wajib pajak. Melalui pemberian materi sosialisasi mengenai perpajakan hotel maka wajib pajak akan dapat mengetahui, memahami dan melaksanakan kewajiban pajak hotel dengan baik. Kurangnya sosialisasi akan berdampak pada rendahnya pengetahuan terhadap pajak perhotelan yang menyebabkan rendahnya kesadaran wajib pajak hotel untuk melaporkan dan membayar pajak yang pada akhirnya mungkin menyebabkan rendahnya tingkat kepatuhan wajib pajak hotel tersebut. 
Sesuai dengan teori legitimasi, jika dalam sistem di perusahaan tidak ada keselarasan dengan sistem nilai dari masyarakat maka perusahaan tersebut akan kehilangan legitimasinya yang dapat mengancam kelangsungan hidup perusahaan. Sosialisasi yang diberikan kepada masyarakat dimaksudkan untuk memberikan pengertian kepada masyarakat akan pentingnya membayar pajak, sehingga dengan adanya sosialisasi ini masyarakat menjadi mengerti dan paham tentang manfaat membayar pajak.

Hasil penelitian ini juga sesuai dengan penelitian yang dilakukan oleh (Hartana \& Merkusiwati, 2018) yang menunjukkan bahwa variabel sosialisasi perpajakan berpengaruh positif pada kepatuhan wajib pajak.

Berdasarkan Tabel 10. diperoleh nilai t hitung sebesar 5.618 sedangkan nilai t tabel sebesar 3.178, dan nilai signifikansi uji t yakni nilai $p$-value sebesar 0,000 $<0,05$ dengan nilai koefisien regresi sebesar 0,391. Ini berarti bahwa sanksi perpajakan berpengaruh positif pada kepatuhan wajib pajak hotel, sehingga hipotesis ketiga penelitian ini diterima.

Hasil analisis menunjukkan bahwa sanksi perpajakan berpengaruh positif dan signifikan terhadap kepatuhan wajib pajak. Semakin berat sanksi perpajakan yang diberikan maka kepatuhan wajib pajak juga akan semakin baik. Ini berarti bahwa apabila sanksi perpajakan yang diterapkan semakin memberatkan wajib pajak maka akan cenderung meningkatkan kepatuhan wajib pajak dalam membayar pajak hotel Kabupaten Badung. Begitu juga sebaliknya semakin ringan sanksi pajak yang diberikan pada wajib pajak yang melanggar peraturan, maka 
tidak akan mampu membuat wajib pajak jera, sehingga kepatuhan wajib pajak akan semakin menurun.

Pengaruh sanksi perpajakan terhadap kepatuhan wajib pajak hotel dalam penelitian ini sesuai dengan teori atribusi. Sesuai dengan teori atribusi, sanksi pajak termasuk dalam penyebab eksternal karena adanya pengaruh persepsi wajib pajak dalam membuat penilaian mengenai perilaku kepatuhan wajib pajak dalam melaksanakan kewajiban perpajakan. Berdasarkan teori pembelajaran sosial, wajib pajak dapat belajar melalui proses pengalaman dan pengamatan dalam pemberian sanksi pajak oleh aparat pajak kepada wajib pajak yang melanggar norma perpajakan.

Penelitian ini mendukung hasil penelitian (Rahayu, 2010) yang menunjukkan hasil bahwa sanksi perpajakan berpengaruh terhadap kepatuhan wajib pajak hotel. Hasil penelitian ini juga didukung oleh hasil penelitian yang dilakukan oleh (Pratiwi \& Setiawan, 2013) yang menyatakan bahwa terdapat hubungan yang positif dan signifikan antara sanksi perpajakan terhadap kepatuhan pajak, yaitu jika wajib pajak memandang bahwa sanksi perpajakan akan memberikan banyak kerugian, untuk selanjutnya sanksi perpajakan dapat memberikan pelajaran bagi pelanggar pajak dan meningkatkan kepatuhan wajib pajak.

\section{SIMPULAN}

Berdasarkan pembahasan hasil penelitian di atas, dapat disimpulkan bahwa kondisi keuangan perusahaan, sosialisasi perpajakan, dan sanksi perpajakan 
berpengaruh positif pada kepatuhan wajib pajak hotel. Sedangkan saran yang dapat diberikan dalam upaya meningkatkan kepatuhan pajak hotel sebaiknya Badan Pendapatan Daerah Kabupaten Badung memberikan bimbingan dan penyuluhan serta memberikan sosialisasi secara berkelanjutan dengan efektif dan berkesinambungan. Selain itu, Badan Pendapatan Daerah Kabupaten Badung sebaiknya juga membuat sanksi perpajakan secara tegas, adil dan berkekuatan hukum yang tetap sesuai dengan perundang-undangan yang berlaku, untuk meningkatkan kepatuhan wajib pajak hotel di Kabupaten Badung. Petugas pajak juga harus lebih aktif dalam memberikan informasi dan pemungutan pajak kepada wajib pajak sehingga wajib pajak tahu kapan membayar dan terhindar dari sanksi administrasi.

\section{REFERENSI}

Aryobimo, p. T. (2012). Pengaruh persepsi wajib pajak tentang kualitas pelayanan fiskus terhadap kepatuhan wajib pajak dengan kondisi keuangan wajib pajak dan preferensi risiko sebagai variabel moderating.

Chau, g. And p. L. (2009). A critical review of fisher tax compliance model.

Clotfetler, c. (1983). Tax evasion and tax rates.

Doran, m. (2009). Tax penalties and tax compliance.

Hartana, i. M. G., \& merkusiwati, n. K. L. A. (2018). Sosialisasi perpajakan memoderasi pengaruh kesadaran wajib pajak dan sanksi perpajakan pada kepatuhan wajib pajak, 25, 1506-1533.

Kristina, \& hariyani, z. Dan e. (n.d.). Pengaruh kesadaran wajib pajak, kualitas pelayanan, ketegasan sanksi dan kewajiban moral terhadap kepatuhan wajib pajak dalam membayar pajak reklame (studi kasus dinas pendapatan daerah kota pekanbaru), 1-15.

Kusuma, k. C. (2016). Pengaruh kualitas pelayanan pajak, pemahaman peraturan perpajakan serta sanksi perpajakan terhadap kepatuhan wajib pajak orang 
pribadi dalam membayar pajak tahun 2014.

Laksono, s. (2012). Pengolahan biologis limbah batik dengan media biofilter.

Lederman, 1. (2003). The interplay between norms and enforcement in tax compliance.

Lidya, w. O. (2013). Sosialisasi perpajakan, pelayanan fiskus dan sanksi perpajakan, 1(3), 960-970. Https://doi.org/issn 2303-1174

Mardiasmo. (2011). Perpajakan.

Martin. (2010). Taxpayers attitudes and tax compliance behavior in kenya.

Pratiwi, i. G. A. . A. M. A., \& Setiawan, P. E. (2013). Reklame di dinas pendapatan kota denpasar fakultas ekonomi dan bisnis universitas udayana ( unud ), bali, indonesia melakukan tindakan penghindaran , pengelakan dan pelalaian pajak yang pada akhirnya akan oleh beberapa faktor, salah satunya adalah kesad. E journal akuntansi udayana, 1, 139-153.

Prayatni, p. T. D., \& jati, i. K. (2016). Pengaruh kondisi keuangan perusahaan, pemeriksaan pajak dan sikap wajib pajak terhadap kepatuhan wajib, 17, 663689.

Rahayu, d. (2010). Analisis Pengaruh Pemeriksaan Pajak terhadap Kepatuhan Wajib Pajak pada Kantor Pelayanan Pajak Pratama semarang selatan, 1-15.

Sapriadi, d. (2013). Pengaruh kualitas pelayanan pajak, sanksi pajak dan kesadaran wajin pajak terhadap kepatuhan wajib pajak dalam membayar pbb (pada kecamatan selupu rejang), 1-27.

Sentanu, i. N. W., \& setiawan, p. E. (2016). Sanksi perpajakan pada kepatuhan wajib pajak hotel, 16, 306-332.

Sugiyono. (2016). Metode penelitian kuantitatif, kualitatif, dan r\&d.

Sulistyaningrum. (2009). Kualitas pelayanan administrasi dan sosialisasi perpajakan terhadap tingkat kepatuhan wajib pajak (studi kasus pada kpp pratama jakarta setiabudi satu).

Torgler, b. (2005). Direct democracy and tax morale. 